\section{Remand to Hospital for a Report}

\section{DeAR SIRS}

I would like to add my support to the concern of Drs Finnegan and Higgins (Bulletin, November 1985, 9, 226) about the lack of treatment provisions under Section 35 of the 1983 Mental Health Act.

Two months ago I was telephoned from a magistrates' court by a defendant's solicitor asking if I would accept a patient under Section 35. I felt I had to decline because such a section did not allow for compulsory treatment. Although until the phone call I had no knowledge of the court case or the charges against the patient, she had been admitted briefly some weeks before but had refused all treatment and discharged herself after a few days.

The solicitor, and subsequently the magistrates, accepted my suggestion that a Remand to Hospital for Treatment (Section 36) would be more appropriate as this section contains a provision for compulsory treatment. Unfortunately, an order under Section 36 can only be made by a Crown Court and so the patient was remanded in custody to await a Crown Court appearance. This Crown Court appearance did not take place until four weeks later and during this time she was held in a Remand Centre, where she caused severe difficulties which were relieved only by getting oral medication into her surreptitiously-and presumably outside the terms of Consent to Treatment provisions. Eventually she arrived at this hospital under my care and is making an extremely satisfactory response to treatment.

In this case the whole purpose of Sections 35 and 36that mentally ill people before the court are able to go to hospital rather than prison-was denied and an inappropriate and unnecessary period of detention in custody amend some details of the 1983 Act and I would like to suggest that consideration should be given to compulsory treatment under Section 35, which could be more appropriately called a Remand to Hospital for Assessment and Report, having similar treatment provisions to Section 2. Another alternative might be to amend legislation so that it would be possible for a magistrates' court to make a Remand for Treatment under Section 36.

Mid Wales Hospital

Michael A. Hession

Talgarth, Brecon occurred. No doubt there will in time be legislation to

dealt with under Sections 2 and 3 as alcoholism itself is specifically excluded by the Act. I attach a copy of the correspondence.

\section{Dear Dr Culliford}

\section{Mental Health Act}

Further to my letter of 22nd February, I have now heard from our solicitors and quote verbatim from his Opinion:*

The answer to his enquiry lies, I think, partly in the old legislation, and partly in the new. For the old Mental Health Act 1959 to apply, there had to be mental disorder, defined as "mental illness, arrested or incomplete development of mind, psychopathic disorder and any other disorder or disability of mind". Mental illness was not further defined in the 1959 Act, nor was it specifically defined in the 1983 Act. The 1959 Act indicated that no one should be dealt with under the powers of the Act "by reason only of promiscuity or other immoral conduct".

'A part of the general review of Mental Health legislation was embodied in the report of the Committee on Mentally Abnormal Offenders, chaired by Lord Butler, which reported in 1975. Among other things, it looked at sexual deviancy and drug or alcohol dependence and the Butler Committee recommended that it would be wrong to allow the use of compulsory powers in such circumstances.

In practice, I understand that alcoholics and drug addicts have sometimes in the past been admitted for short periods for observation on the basis that they were suffering from "any other disorder or disability of mind".

'Your member is quite right in his approach. Section 1 (3) of the Mental Health Act 1983 states that "nothing in this section shall be construed as implying that a person may be dealt with under this Act as suffering from mental disorder or from any form of mental disorder described in this section, by reason only of promiscuity or other immoral conduct, sexual deviancy or dependence on alcohol or drugs".

'It would therefore be inappropriate to implement sections 2 or 3 of the Mental Health Act, by reason of alcohol dependence alone. This is, I understand, regarded as a social and behaviour problem, rather than mental disorder.

'From this point on we are into matters of clinical judgement. If the responsible medical officer considers that there is delirium tremens or alcoholic dementia which takes the patient into another category amounting to mental disorder, then the Act may apply and compulsory admission might be justified. That will be for the doctor to say.'

I trust that this is of some assistance.

Yours sincerely

G. J. ROBERTS Medical Defence Union

\section{Alcoholism and the Mental Health Act}

DeAr Sirs

I recently had occasion to write to an official of the Medical Defence Union in order to clarify whether or not under the 1983 Mental Health Act patients with delirium tremens (and also, perhaps, alcoholic dementia) could be
*Source for preamble to Opinion: R. Bluglass (1983) A Guide 10 the Mental Health Act 1983. London \& Edinburgh: Churchill Livingstone.

L. D. CULliford

St George's Hospital

Blackshaw Road, London SW17 